\title{
AYURLOG
}

National Journal of Research in Ayurved Science

http://www.ayurlog.com

Nov- 2020 | Volume 08 ${ }^{\text {th }} \mid$ Issue: $6^{\text {th }}$

ISSN: 2320-7329

\section{Review about Adhyashana as a causative factor in Grahanidushti from Charak Samhita.}

\section{Chavan Vinita S. ${ }^{1}$, Bhandare Vijay M. ${ }^{2}$, Chaudharri Manojkumar V.*3}

1. B.A.M.S., M.D. Scholar (Samhita and Siddhanta),

E-mail : vinitachacan1429@gmail.com,

Mobile : 9970456728.

2. M.D. (Ayurved Samhita), M.D. (Kayachikitsa), Professor and HOD,

E-mail : drvijaybhandare@gmail.com, Mobile: 9422080246.

3. M.D. (Ayurved Samhita), Ph.D. (Ayurved Samhita), Assistant Professor,

Department of Samhita and Siddhanta,

Ashtang Ayurved Mahavidyalaya, Pune, Maharashtra

*Corresponding Author: E-mail : manojsamhita@gmail.com, Mobile : 9021255057.

\begin{abstract}
:
Grahanidushti or Grahaniroga is associated with group of disorders caused due to Agnidushti. Grahani is an organ described in Ayurveda texts as a Sthana of Agni where the Agni is placed. Grahani and Agni are said to be inter-related i.e. if one gets vitiated it vitiates other too in long course of time. The Sthiti or state of Agni depends upon Ahara which is a major important part of life which is included in Trayopastambha (key pillars). For that Ayurveda broadly explains Ahara-Vidhi which is the rules and manners for preparing and having food. Vidhi-tyaga or not following these manners for long term give
\end{abstract}

rise to Agnidushti which further give rise to Grahaniroga.

One of these Vidhi-Tyaga hetu is Adhyashana which is having food before the digestion of previously ingested food. Ayurevda explains Jeernashana as a Vidhi which is to have food after the complete digestion of previous food. Incidence of Adhyashana has increased as increasing modernization of society. Also, the incidence of Grahaniroga has increased very much and both should be addressed. As the treatment for Grahaniroga is AgniVardhana or Deepana, Hetu-Privarjana i.e. avoiding causative factor is very important. 
To address this, an attempt is made to review Adhyashana in Grahanidushti.

\section{KEYWORDS :}

Adhyashana, Grahanidushti or roga, Agni, Ahara-Vidhi.

\section{INTRODUCTION :}

Ayurveda always gives due importance to the preventive aspects so that the features of healthy person (swasthapurusha) mentioned in the Ayurveda texts can be achieved. ${ }^{[1]}$

Ayurveda describes Agni as the prime reason (hetu) to be healthy when not vitiated (Avikrutaavastha) and leads to many hazardous health issues even death if it is vitiated (Dushta or Vikruta). ${ }^{[2]}$ Thus, gives rise to Grahanidushti as it is Agni Adhishthana $^{[3]}$ i.e. where the Agni is placed.

To maintain Agni, Ayurveda has elaborately described the Ahara-vidhi ${ }^{[4]}$ i.e. rules to follow while taking food or for diet to maintain healthy Agni and in turn maintain health.

In the present era, due to competitiveness in each and every field of life with modernization, today's individual does not get sufficient time for taking food and maintain its quantity and quality and tend to forget the rules which are followed traditionally merely given in $\mathrm{d}$ Ayurveda texts. Ayurveda explains on manner of having food is to have food after the complete digestion of previously ingested food which is called as Jeernashana which shows various symptoms when the food is completely digested as Udgarashuddhi, Vatanulomana, Kshudbodha etc. ${ }^{[5]}$
Adhyashana which means having food before the digestion of previously ingested food ${ }^{[6]}$, has become very common dietary habit and trend in modern developed area. It is one of the most important factor to vitiate the Agni which contributes majorly to cause many digestive disorders especially Grahanigada. Adhyashana may give rise to various other hazardous diseases (Ghora Vyadhi) in long term mainly causing Agnidushti. ${ }^{[7]}$

As the increase in modernization, there is increase in haphazard manner of Ahara (diet) and Vihara (lifestyle) which is causing various disorders. Changes in food habits manily cause Agnidushti and give rise to multiple diseases specifically Grahani. As the treatment for Grahaniroga is AgniVardhana or Deepana ${ }^{[8]}$, Hetu- Privarjana i.e. avoiding causative factor is very important. To address this, an attempt is made to review Adhyashana in Grahanidushti.

\section{AIMS AND OBJECTIVES :}

1.To study the wide concept of Agni and Grahani from Charak Samhita and focus on Hetu Adhyashana.

2. To disclose the concept Ahara-Vidhi i.e. manners and methods while having food.

\section{MATERIALS AND METHODS :}

Total Ayurvedic material related to the topic was studied from Bruhattrayee specifically Charak Samhita.

\section{DISCUSSION :}

\section{Agni :}

As mentioned, Ayurveda Shastra gives due importance to the Agni as it 
performs very important role in digestion, assimilation of food and thus maintains the Sthiti of health (health status as it is) and achieve the features of healthy being. Agni in its Prakruta Avastha i.e. if not vitiated or not dushta, gives Ayu (longetivity which is mentioned as Chetananuvrutti), Varna (Prakruta complexion of that indiviadual, not Panduta or Karshnya etc.), Bala (strength), Swasthya (health), Utsaha(enthusiasm), Upachaya(accural of body), Prabha(radiance), Oaj, Teja(luster or glow), and Agni(other types of Agni). ${ }^{[2]}$ Grahanigada occurs only if Agni is vitiated because of various reasons. Ashtanga Sangraha also states that Bala of a person is dependant on Agni and life and its longetivity are dependent on Bala (Jeevita). So Agni should be kept healthy. अग्रिमूलं बलं पुंसां बलमूलं हि जीवितम् । [9]

\section{- $\quad$ अ.सं.चि. १२/३?}

\section{Grahani :}

Grahani is the organ where Agni is placed (Agni adhishthana). Agni and Grahani have Adhara - Adheya relation i.e. Grahani is Adhara to Agni and Agni is Adheya. As it holds food (Dharan of Anna), it is called as Grahani.

अग्यधिष्ठानमन्नस्य ग्रहणाद्रहणी मता । [3]

-च. चि. $9 \varphi / 4 \xi$

Long term exposure to Agnidushti $\mathrm{Hetu}$ (causative factors to vitiate Agni), give rise to Dushtagni and cause various diseases. But not only this, it gives rise to Grahaniushti as well and it becomes a vicious cycle. Grahani is situated above Nabhi (navel) and gets support as well as nourishment from healthy Agni. Thus,
Grahani strengthens Agni and Grahani gets strengthened by Agni. ${ }^{[3]}$

Grahani is an important entity which helps in digestion of food as it holds undigested food and pushes forward digested one. ${ }^{[10]}$

\section{Adhyashana :}

Charak has described Adhyashana as the prime reason (hetu) for Grahanidushti, which means having food before the digestion of previously ingested food. भुक्तं पूर्वान्नशेषे तु पुनरध्यशनं मतम् । [6]

$$
\text { -च. चि. १५/२३६ }
$$

Long term exposure to Adhyashana causes gradual decrease in Agni (Mandagni) and thus, give rise to many diseases specifically Grahanigada. As the previous food is not digested, Ama is produced, all the doshas are provoked and in turn it becomes a vicious cycle giving rise to more production of Ama. Ama is said to be acting as Visha in human body ${ }^{[11]}$, which attributes to many diseases and death also. Vagbhata has said to be Varjya as its Viruddhopakramatwa and Visha swaroopa. ${ }^{[12]}$

References of Adhyashana in Charak Samhita -

*Ch. Su.- $14 / 10$

*Ch.Su.- 25/40.

*Ch.Vi.- 2/12.

*Ch.Vi.- 5/21.

Adhyashana is mentioned as prime hetu or reason for Grahanigada as well as-

* Grahani-Ch. Chi. 15/236.

* Aamavisha-Ch. Vi. 2/12.

* Pittaja Gulma - Ch. Ni. 3/4.

* Kushtha-Ch. ni. 7/6.

* Udar roga-Ch. Chi. 13/26.

*In Siddhisthana of Charak Samhita, Adhyashana is one of the factors of Ashta Mahadoshakara bhava in Karma chikitsa. It 
causes Mukhashosha,Adhmana, Shoola etc. Ahara- Vidhi regarding Adhyashana : Food should be taken after the complete digestion of food which is called as Jeernashana. ${ }^{[5]}$

Agni should be maintained healthy with the help of proper diet, which gives health and strength to a person for longetivity of life. If the Vidhi i.e. these rules are not followed well give rise to mainly Grahanidoshaja roga.

यो हि भुङ्क्ते विधिं त्यक्त्वा ग्रहणीदोषजान् गदान्। स लौल्याल्लभते शीघ्रं..... ॥ - च.चि. १५/४१[13]

\section{Grahanigada :}

In Grahanidosha, there is no pattern in defeacation that is sometimes it's with undigested food particles, or may be if properly digested proper stool is passed or there is no motion or may be sometimes hard or loose stools may pass. ${ }^{[14]}$ Chakradatta explains Grahanidosha as Grahani ashrita roga. Mandagni specifically acts major role in Grahanidushti. Causative factor mainly Adhyashana in this study specifically causes Mandagni. It has 4 types - Vataja, Pittaja, Kaphaja and Tridoshaja.

Samanya Grahani lakshana include frequent stools or constipation or Loose motions, delayed

digestion,thirst,ageusia,driveling,dizziness,fe et and hand oedema, finger joint pain, vomiting, fever,belching. ${ }^{[15]}$

\section{Samprapti of Grahaniroga :}

Hetusevana

(Aharaja - Adhyashana, Vishamashana, Asatmya etc.

Viharaja - Desha, Kala, Rutu vaishamya, Veg-vidharana etc.)

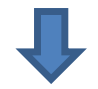

Agnidushti

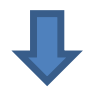

Apachana (Indigestion)

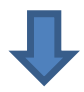

Amotpatti, Shuktapaka

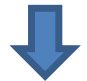

Amavisha (Localised at GIT level, Generalise whole body)

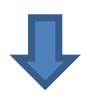

Grahani Dosha

\section{Treatment for Grahanigada :}

As it is Chirakari Vyadhi, caused due to long term exposure to causative factors, Chikitsa also is a long term process with lot of food restrictions (pathya).

Main Chikitsa is Agni Deepana through every way possible. ${ }^{[8]}$ Also, Nidana parivarjana is very important factor to treat Grahani or any disease. Here, in this case, avoiding Adhyashana and following AharaVidhi is the treatment.

\section{CONCLUSION :}

Agni and Grahani are very broadly explained in Charak Samhita. Also, Ahara $V i d h i$ is explained which explains manners while having food.

Adhyashana and thus Ahara vidhityaga is 
increasing on large scale with increasing westernization giving rise to various lifestyle disorders. It mainly causes Agnidushti. Adhyashana is specifically mentioned to cause Ghora vyadhi and may cause death also according to text. Not only Grahani but it also causes many other hazardous diseases.

Adhyashana specifically cause Mandagni and Purishavaha Srotodushti.

Knowledge of Ahara vidhi, Vidhityaga as a causative factor will help subjects to reduce or avoid hetu and reducing incidence of Agni or Grahanidushti. It will also make people see the preventive side (Swasthavritta) of Ayurevda.

\section{REFERENCES :}

1) Yadavji Trikamji Acharya, Narayana Ram Acharya, Sushruta Samhita, Nibandhasangraha commentary by Dalhana, Varanasi, Chaukhamba Publications, Reprint2014,Sootrasthana, Chapter no.15, Shloka no. 41, Page no. 75.

2) Yadavji Trikamji Acharya, Charak Samhita, Ayurved-Deepika commentary by Chakrapani, Varanasi, Chaukhamba Prakashana, Reprint-2013,Chikitsasthana,

Chapter no. 15, Shloka no. 3,4, Page no. -512 .

3) Yadavji Trikamji Acharya, Charak Samhita, Ayurved-Deepika commentary by Chakrapani, Varanasi, Chaukhamba Prakashana, Reprint-2013,Chikitsasthana, Chapter no. 15, Shloka no. 56, Page no.-517.

4) Yadavji Trikamji Acharya, Charak
Samhita, Ayurved-Deepika commentary by Chakrapani, Varanasi, Chaukhamba Prakashana, Reprint-2013,Vimanasthana, Chapter no. 1, Shloka no. 24, Page no.-236.

5) Yadavji Trikamji Acharya, Charak Samhita, Ayurved-Deepika commentary by Chakrapani, Varanasi, Chaukhamba Prakashana, Reprint-2013,Vimanasthana, Chapter no. 1, Shloka no. 25, Page no.-237.

6) Yadavji Trikamji Acharya, Charak Samhita, Ayurved-Deepika commentary by Chakrapani, Varanasi, Chaukhamba Prakashana, Reprint-2013,Chikitsasthana, Chapter no. 15, Shloka no. 236, Page no.-525.

7) Yadavji Trikamji Acharya, Charak Samhita, Ayurved-Deepika commentary by Chakrapani, Varanasi, Chaukhamba Prakashana, Reprint-2013,Chikitsasthana, Chapter no. 15, Shloka no. 237, Page no.-525.

8) Yadavji Trikamji Acharya, Narayana Ram Acharya, Sushruta Samhita, Nibandhasangraha commentary by Dalhana, Varanasi, Chaukhamba Publications, Reprint2014,Uttaratantra, Chapter no.40, Shloka no.182, Page no. 710.

9) Dr.Jyotirmitra Acharya,Ashtanga Sangraha

Vruddhavagbhta,Shashilekha commentary by Indu, , Varanasi, Chaukhamba prakashana,Reprint2016,Chikitsasthana,Chapter no.12,Shloka no.31, Page no.508.

10) Yadavji Trikamji Acharya, Charak 
Samhita, $\quad$ Ayurved-Deepika commentary by Chakrapani, Varanasi, Chaukhamba Prakashana, Reprint-2013,Chikitsasthana, Chapter no. 15, Shloka no.57, Page no.-517.

11) Yadavji Trikamji Acharya, Charak Samhita, Ayurved-Deepika commentary by Chakrapani, Varanasi, Chaukhamba Prakashana, Reprint-2013,Vimanasthana, Chapter no. 2, Shloka no.12, Page no.-239.

12) Dr.Anna Moreshwar Kunte,Pt.Krushnashastri Navare, Ashtanga Hrudaya, Varanasi, Chaukhamba Prakashana, Reprint2012,Sootrasthana, Chapter no.8,Shloka no.13,14,Page no.150.

13) Yadavji Trikamji Acharya, Charak Samhita, Ayurved-Deepika commentary by Chakrapani,
Varanasi, Chaukhamba Prakashana, Reprint-2013,Chikitsasthana, Chapter no. 15, Shloka no.41, Page no.-516.

14) Yadavji Trikamji Acharya, Charak Samhita, Ayurved-Deepika commentary by Chakrapani, Varanasi, Chaukhamba Prakashana, Reprint-2013,Chikitsasthana, Chapter no. 15, Shloka no.51-52, Page no.-517.

15) Yadavji Trikamji Acharya, Charak Samhita, Ayurved-Deepika commentary by Chakrapani, Varanasi, Chaukhamba Prakashana, Reprint-2013,Chikitsasthana, Chapter no. 15, Shloka no.51-54, Page no.-517.

\section{Cite this article:}

"Review about Adhyashana as a causative factor in Grahanidushti from Charak Samhita."

Chavan Vinita S., Bhandare Vijay M., Chaudharri Manojkumar V.

Ayurlog: National Journal of Research in Ayurved Science- 2020; (8) (6):01- 06 